Hospital in Houston, Texas, and W. Szybalski of McArdle Laboratory in Madison, Wisconsin, and it was first reported in February 1961 at the Fifteenth Annual Symposium on Fundamental Cancer Research, M. D. Anderson Hospital and Tumor Institute, Houston, Texas (The Molecular Basis of Neoplasia, University of Texas Press, Austin, Texas, pp. 136 and. 164).

\section{Yours faithfully,}

WACLAW SZyBaLSKI

McArdle Laboratory,

University of Wisconsin,

Madison, Wisconsin.

\section{University News}

THE following appointments have been made to chairs in the University of Edinburgh : Mr James T. Baxter to the William Dick chair of veterinary medicine; Dr H. J. Walton to the second chair of psychiatry; Dr Eric Samuel to the Forbes chair of medical radiology.

Dr N. S. Kirk has been appointed to a personal chair in ergonomics, and Dr G. R. Wray has been appointed to a personal chair in the Department of Mechanical Engineering, both in Loughborough University of Technology.

Dr Peter H. Elworthy, University of Strathclyde, has been appointed to the chair of pharmacy in the University of Manchester, in succession to Professor Kenneth Bullock.

Dr Robert A. Sack has been appointed to a personal chair in the Department of Mathematies, University of Salford.

Dr S. A. Robertson, University of Liverpool, has been appointed to the chair of pure mathematies in the University of Southampton.

\section{Appointments}

Mr J. D. Platt, head of the Components Department at the Electrical Quality Assurance Directorate, has been appointed director of the British Calibration Service, in succession to Mr H. E. Barnett.

\section{Announcements}

AT a meeting of the Society for Low Temperature Biology on March 20, the John Scott award of the City of Philadelphia for 1969 was presented to Sir Alan Parkes, Dr Audrey Smith and Dr Christopher Polge.

Dr T. Brooke Benjamin, University of Cambridge, has been awarded the 1969 William Hopkins prize of the Cambridge Philosophical Society for his work on the mechanics of fluids with applications to engineering and geophysies.

THE International Union Against Cancer, with funds from the American Cancer Society, will award fellowships to experienced investigators engaged in clinical or experimental cancer research, who wish to spend a period of study at a single institution abroad. Applications must be submitted before September I. Further details can be obtained from International Union Against Cancer, PO Box 400, 1211 Geneva 2, Switzerland.

Frratum. The title of the article by Jay A. Levy and Robert J. Huebrer (Nature, 225, 949; 1960) should read "Association of a Murine Leukaemia Virus from a Mouse Lymphoma (2731/L) associated with Reovirus Type 3 Infection".

Erratum. In the titlo of the article by J. Ken McDonald, Benjamin B. Zeitman and Stanley Ellis (Nature, 225, 1048; 1970 ), the word "appropriate" should read "inappropriate".

\section{International Meetings}

April 20-24, Coordinate Indexing, London (Education Officer, Aslib, 3 Belgrave Square, London SW1).

April 21-23, Introduction to Mechanization, Strathclyde (Education Officer, Aslib, 3 Belgrave Square, London SW1).

April 29, The Food-People Balance, Washington DC (National Academy of Engineering, 2101 Constitution Avenue NW, Washington DC, 20418, USA).

May 18-21, The Photosynthetic Unit, Gatlinburg (Robert M. Pearlstein, Oak Ridge National Laboratory, Post Office Box Y, Oak Ridge, Tennessee 37830, USA).

May 19-21, Signal Processing Methods for Radiotelephony, London (Manager, Conference Department, Institution of Electrical Engineers, Savoy Place, London WC2R OBL).

May 21-22, International Computing Symposium 1970, Bonn (C. R. Rudolph, ACM Conference Registration, c/o Gesellschaft für Mathematik und Datenverarbeitung, 5201 Birlinghoven (Schloss), Germany).

June 2-5, Pollution and Lung Biochemistry, Richland (Dr J. N. Roehm, Battelle-Northwest, Po Box 999, Richland, Washington 99352, USA).

June 3, Clinical and Metabolic Aspects of Laevulose, London (Sydney Lee, Calmic Limited, Crewe, Cheshire).

June 16, Prevention of Cancer, London (Assistant Secretary, Marie Curie Memorial Foundation, 124 Sloane Street, London SW1).

June 22-July 3, The Physics of Quantum Electronics, Prescott Arizona (Professor S. F. Jacobs, Optical Sciences Centre, University of Arizona, Tucson, Arizona 85721, USA).

June 29-July 10, Health Physics (summer school), London (Registrar, Imperial College, South Kensington, London SW7).

July 3, Polymer Composites, Cardiff (Organizer of Short Courses, University of Wales Institute of Science and Technology, 22 North Road, Cardiff CFl 3DY).

August 17-30, Disarmament and Arms Control (summer school), Duino, Trieste (C. Schaerf, Laboratori Nazionale di Frascati, Casella Postale 70, 00044 Frascati, Rome, Italy).

August 31-September 5, Heat Transfer, Paris (Société Française des Thermiciens, 28 Rue de la Source, 75 P'aris 16, France).

September 7-9, Ion Implantation, Reading (Meetings Officer, The Institute of Physies and the Physical Society, 47 Belgrave Square, London, SW1).

September 7-10, Polyvinyl Chloride: its Formation and Properties, Prague $(\mathrm{O}$. Wichterle, Institute of Macromolecular Chemistry, Czechoslovak Academy of Sciences, Prague, Czechoslovakia).

September 7-11, Gontrol Mechanisms of Growth and Differentiation, Kent (Professor P. J. Syrett, Department of Botany, University College, Swansea).

September 9-11, Crystal Growth, Bristol (Dr D. Elwell, Physics Department, Portsmouth Polytechnic, Park Road, Portsmouth POl 2D7).

September 9-11, Third Canadian Medical and Biological Engineering Conference, Halifax (Conference Secretariat, Nova Scotia Technical College, PO Box 1000, Halifax, Nova Scotia, Canada).

September 12-15, Research Conference of the European Group for the Study of Lysosomes, Louvain. (EGSL, c/o Dr P. J. Jacques, 6 Dekenstraat, 3000 Louvain, Belgium). 